\title{
脚気及び脚気様状態の分析的研究
}

\author{
東邦大学医学部内科第二講座（指尊 阿部達夫教授） \\ 安 部井徹
}

\section{ANALYTIC STUDIES ON BERIBERI AND BERIBERI-LIKE STATE}

BY

\section{Tooru Abei}

The Second Clinic of Medicine, School of Medicine, Tohō University, Tokyo

(Prof.: Tatsuo Abe)

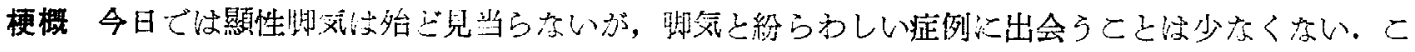

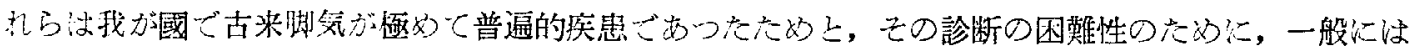

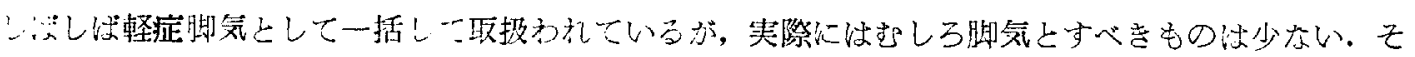
こで私は軽泣明気の讋断法を多力䤄心ら检討し，乙れらの患者の中から真の脚気を分離し，ついで残

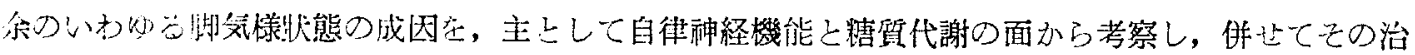

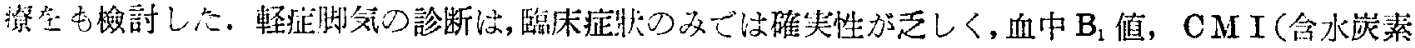

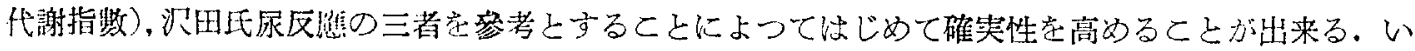

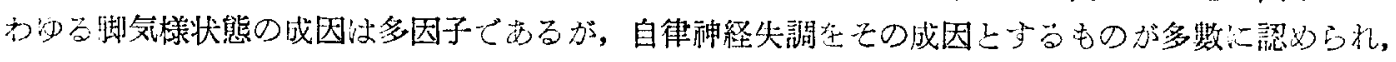

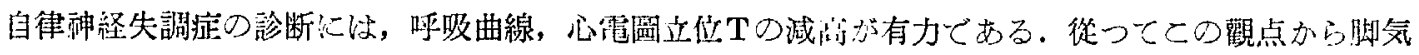

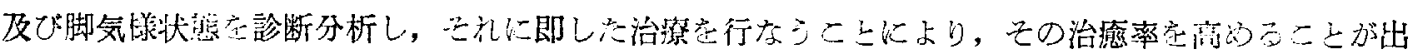
来产.
\end{abstract}

緒 言

近時典型的な脚気が殆ぞ見当らなくなつている に拘らず，軽症脚気乃至は不全型脚気或はこれと 極めて紹らわしい症例を見ることは非常に多く， 篠猗1) は外来初診者の $5.6 \%$ に認め, 柳2) 注最盛 期の夏期には外来初榕総数の $20 \% に も$ 達すると云 っている。

古来脚気はわが国では極めて普遍的な聅患であ つた関係上，一般にこのような患者の多くは，單 に臨床症状のみから，ビタミン $\mathrm{B}_{1}$ (以下 $\mathrm{B}_{1}$ ）久 乏症と見なされ，慢然と $B_{1}$ 剂によつて治療され る傾问にある，その中には勿論 $\mathrm{B}_{1}$ 欠乏があつて

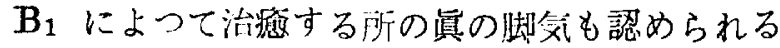

が，むしろ B $_{1}$ 郕の無效なものも可成りに存在し， しかもその原因が掴み難く，種々の治療に抗して 治り難い場合も少なくない。

このような一群の患者は従来一括して脚気様状 態又は脚気様症状群などと呼ばれて，脚気とは区 別されている．しかし顕性脚気の診断が容易であ るに反し，軽症脚気ではその確証を得ることが非 常に煩雑かつ困難であり，従来臨床症状から雨者 を鑑別する種々の試みがなされているが，必ずし も正確を期することが出来ず，佐乃3）は場合によ つては殆ど不可能に近いと云い，篠崎1)も症状の みによる分類では両者間に確然とした一線を画し 難いことを認めている。 


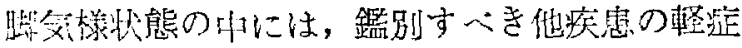
も混在し得るであるうが，それよりも成因の不朋 な当の多く，二の成因に関しては或はB 1 と関 速しで，或は神䌡循㻴琵约症の如き自律神経異

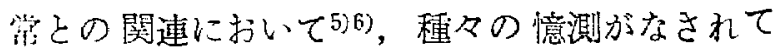

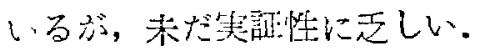

そこで私は，これら一群のまぎらわしい病態よ り率の脚気を如何にして分離するかを梌討し，また いわ泫る脚気梾状態を主として自律神経機能及び

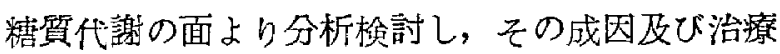
に対し、いさっか知見を得たのでこ〉に報告する。

\section{対象及び実験方法}

昭和30月 1 月から33月12月の 4 年間に脚気様主 挀をもつて，東却大学阿部内科を訪れた患者を竑 象とした。これらの患者の中で一般臨床検查所見 やその後の経過から明らかに別の原因が見出され たものを他疾息として除外し，残りのものを一括

して「脚気及び脚気梯状態」とし，これらに就い て一般臨床症状の他に次の如き諸種の检査を実施 した。

血压，赤沈，尿蛋白・渃・ウロビリノーゲン， 屡潜血反応及び䳋，血液所見，高田反応，于 モール混浊反応，コパルト反応，BＳ P, 心電図, 脸部X線写貪（以上は一般に行なわれている力法

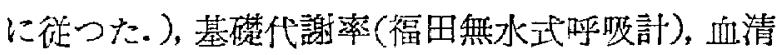
$\mathrm{Na} ＼textrm{K}$ (ベックマン氏分光々度計)，血清蛋白量

（日立血清蛋白計）及びその分屑像（潈紙電気泳 動法)，尿りロビリノーゲンはレフェーネ氏法を併 用した。血中 $B_{1}$ 值は早朝空腹時に採血し、ブロム シアン・チオクローム法にて八木式巣光々度計を 用いて測定した。沢田氏尿反応は一部は最新の改 良法》によつた。含水炭菜代謝指数（CMI）注 Horwitt \& Kleisler ${ }^{8)}$ の変法によつた. 即ち空 腹安静時の婜者に20\%ブドウ栫液を体重kg当り 9 cc内服せしめ，60分後 Master の二階段試験によ り䒸動を鿓荷し, 更に5 分の安静後採血し, 血煒 (G)，血中乳酸值（L）及び焦性ブドウ酸值（P） を浿定し， CMI $=\frac{1}{2} （ L+15 P-\frac{G}{5} ）$ を算
出して求めた，血楉は Hagedorn-Jensen 氏法，乳 酸は Parahydroxy diphenyl 法, 焦㤬ブドウ酸 は Friedmann-Haugen 氏法により測定した。

自律神経機能侩查法としては, 在来の各種自律 神経機能検查法の他に呼吸时線, 立位Tの減高正 $ひ ゙$ Wenger 氏の自律神経緊張状態測定法を採用 した。呼吸折線は福田無水式呼吸計を用い，空腹 安静洔の呼吸惟線を描写し，穴の直後出来得る限 り呼吸を停止せしめ，更に深呼吸を出来得尚限り 区復せしめた徯，出来るだけ呼吸を停止せしめ た.これらの呼吸停止時間を測定し(單位秒), 前 者を停止（1）後者を停止（2）之略称した。電 図に於ける立拉Tの減高は，卧位及び立值に扔い

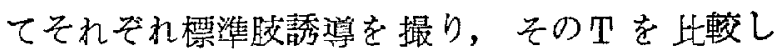
て, 臥位 $\mathrm{T}$ 一立位 $\mathrm{T}(\mathrm{mV})$ を減高の程度とした。

以上の諸秎査成續に $\mathrm{B}_{1}$ 剂, 自律神経安定剤等に よる沿療効果, 調查表による生活状海等を加味し て, 脚気及び脚気様状態を諸種の点から分析した。

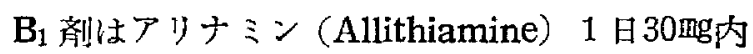
服又は 1 日 $10 \mathrm{mg}$ 静注を 1 週閒試み, 自律神経安定 刋はベレルガル（1 鋔中酒石酸エルゴタミン 0.3 mg, ベラフォリン $0.1 \mathrm{mg}$, フェノバルビタール20.0

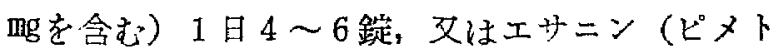
レミッド臭化水素酸塩40mg, キシロプロパミン硫

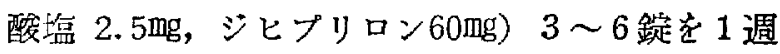
聞試み，臨床症状の消退せるものを有效とした。

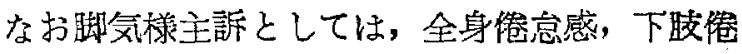

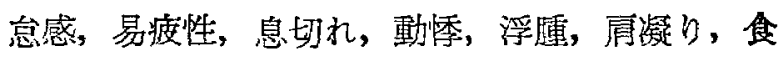
欲不振, 頭痛, 心部不快感, 銦莗, 熱感, 䐧内苦 悶, 四胶シビレ感, 腰痛を取上げた。

\section{実験成績}

I）脚気及び脚気様状態の統訐的観察

脚父椂主訴をもつて外来を訪れる患者は表 1 の 如く, 年閒外来初䇏者総数の13.3〜21.5\%を占め ている. その中脚気及び脚気様状態として一括し た雭者は，年間76人から 87 人，昭和32年度には 277 人の多きに達し,外来初榕㨋総数の $2.8 \sim 7.1$ \%の発生率となっている.

月別にこれを見ると竝 2 の如く，脚気区び脚気 
Tab. 1. A classification of patients with beriberi-like complains in the outpatients of Toho Univ. Hospital and their annual incidence(from 1955 to 1957 ).

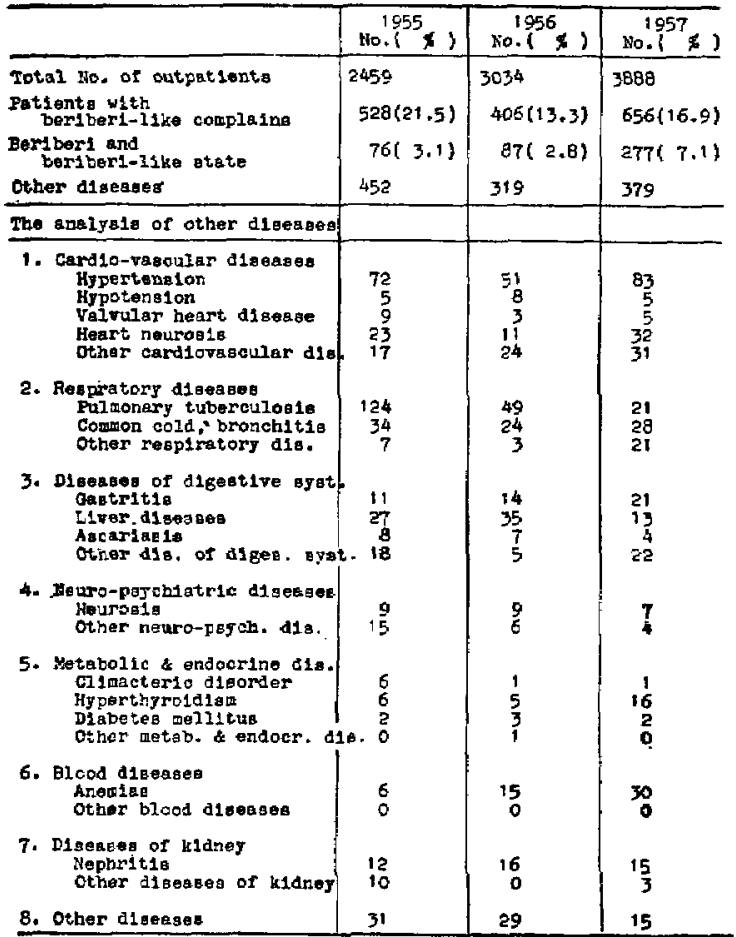

Tab. 2. Monthly distribution of patients with beriberi-like complains, beriberi and beriberi-like states (Total No, of patients in three years.).

\begin{tabular}{|c|c|c|c|}
\hline mon. & $\begin{array}{l}\text { Tatal Ro. of } \\
\text { outpetient: }\end{array}$ & Dotinterith & $\begin{array}{l}\text { Beribori } \\
\text { bortbert-like atete }\end{array}$ \\
\hline Jan. & 2189 & 121 & 20 \\
\hline Fob. & 64 & 122 & 10 \\
\hline mer. & 752 & 127 & 25 \\
\hline Aps. & 753 & 220 & $\mathbf{s 1}$ \\
\hline May & 809 & 160 & 47 \\
\hline Jun. & B16 & 101 & 58 \\
\hline Jux. & 758 & 180 & 68 \\
\hline Lus. & 005 & 162 & 68 \\
\hline sep. & 728 & 145 & 56 \\
\hline oet. & 734 & 122 & 38 \\
\hline Hor. & 767 & 92 & 22 \\
\hline Dese. & 623 & 77 & 14 \\
\hline Totel & 1. 6581 & 1590 & 140 \\
\hline
\end{tabular}

稼状態注 6 ・7・8月の夏期に多く，加っる急者 の42.7\%はこの3カ月間に発生している.
Tab. 3. Distribution of the age among patients with beriberi-like complains, beriberi and beriberi-like state (Total No. in three years.).

\begin{tabular}{|c|c|c|}
\hline$A G E$ & $\begin{array}{l}\text { Patlentg Hith } \\
\text { beriberi-11ike } \\
\text { complains }\end{array}$ & $\begin{array}{c}\text { Ber1ber1 and } \\
\text { ber1ber1-11ke gtate }\end{array}$ \\
\hline Under 20 & 209 & 81 \\
\hline $21-30$ & 558 & $177(40.28)$ \\
\hline $31-40$ & 354 & 110 \\
\hline $41-50$ & 220 & 5.1 \\
\hline Over 51 & 250 & 21 \\
\hline Total No. & 1590 & 440 \\
\hline
\end{tabular}

Tab. 4. Sexual incidence of patients with beriberi-like complains, beriberi and beriberilike state (Total No. of patientts in three years.).

\begin{tabular}{|c|c|c|}
\hline $\operatorname{SEx}$ & $\begin{array}{c}\text { Patfenta Hith } \\
\text { bertbert-intre } \\
\text { cowplaine }\end{array}$ & $\begin{array}{c}\text { Beriter } 1 \text { anō } \\
\text { berl be=1-11ke state }\end{array}$ \\
\hline MALES & 731 & 215 \\
\hline FEMALES & 859 & 225 \\
\hline TOTAL No. & 1590 & 440 \\
\hline
\end{tabular}

年令的には表 3 の如く若年者が大斯分で，21〜 30 才がその $40.2 \%$ 卢めている. 男女間には表 4 の如く差異がない。

II）脚気及び脚気㥞状態の分析

a）血中 $\mathrm{B}_{1}$ 值及び CMI の正常值とその相 関

血中 $B_{1}$ 値及び CMIの正常值の分布は図 1 の

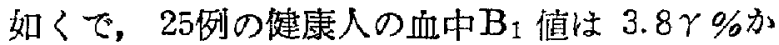
ら $7.6 \gamma \%$ 間にあり，平均值は $5.1 \pm 0.8 \mathrm{r} \%$ であった。8例の健康人のCMIは 5.3 から 14.5

Fig. 1. The histogram of blood thiamine level and carbohydrate metabolic index in normal person.

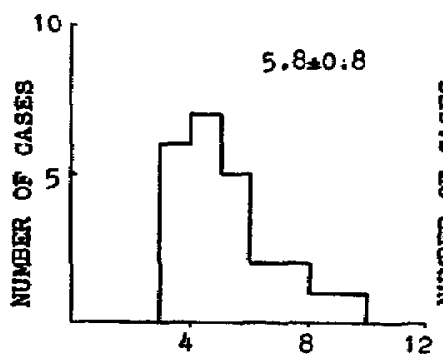

BLOOD THIAHINE LEVEL $(\mathrm{r} / \mathrm{ml})$

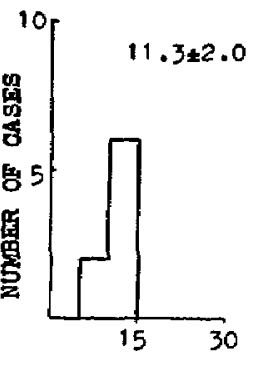

G.M.I. 
Fig. 2. The relationship between blood thiamine level and carbohydrate metabolic index (CMI).

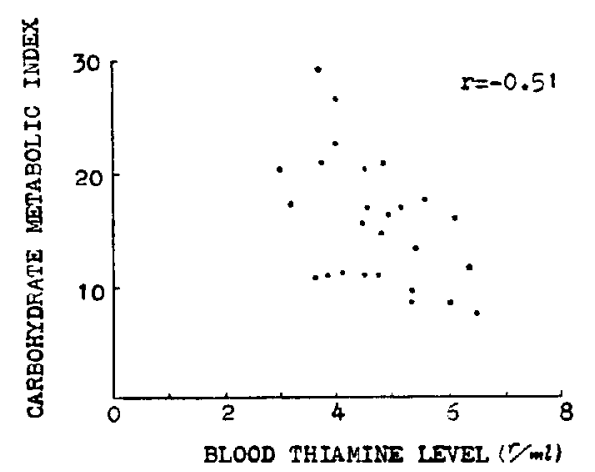

の間にあり，平均佔は11.3土2.0で15を超えるも のはなかつた，血中B 1 倪と C M I の间には図 2

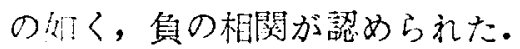

b）他疾患

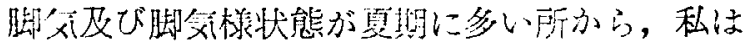
2 作闻に百り，6月から9月の間に来院して一必
Tab. 5. More precise differentiation of the 117 patients who were primarily impressed as beriberi or beriberi-like state.

\begin{tabular}{l|r}
\hline Total No. of patients & 117 \\
\hline Berlber1 and beriber1-11ie etste & 88 \\
\hline Aremias & 10 \\
Hyperthjro1dism & 4 \\
Neuros1s & 4 \\
Gastrit1s and peptic uler & 3 \\
Ascarisa1s & 2 \\
Other different1ated alseases & 6 \\
\hline
\end{tabular}

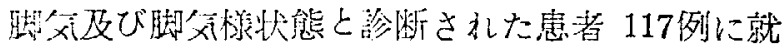

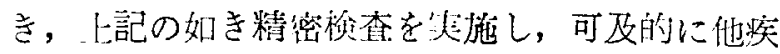
患を除外した。スの結果は装 5 の如く，な扮29例

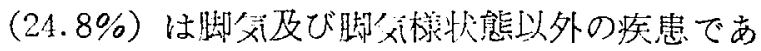
ることを知つた。表 5 の筫㨁は卧 6 の如く臨床症

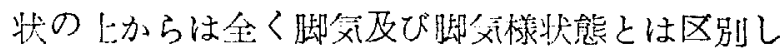
得なかつたもので，血液所見から初めて診断され

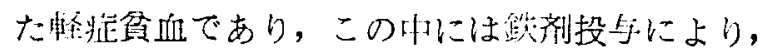

Tab. 6. The symptoms and findings of the patients with anemia who were first impressed as beriberi-like state.

\begin{tabular}{|c|c|c|c|c|c|c|c|}
\hline Caseno. & Agedsex & $\begin{array}{l}\text { Eubjective } \\
\text { syotiotoms }\end{array}$ & $\begin{array}{l}\text { Cbjective } \\
\text { sjuptoms }\end{array}$ & H户 & $\begin{array}{c}\text { Red } \\
\text { ceid } \\
\times 10^{+} \\
\end{array}$ & CI & \\
\hline 1. & 48 & $\begin{array}{l}\text { Lassitude, headache, } \\
\text { palpltation, short- } \\
\text { ness of the breath. }\end{array}$ & $(-)$ & 60 & 303 & 0.99 & \\
\hline 2 . & 44 & $\begin{array}{l}\text { Lassitude, fatigua- } \\
\text { bility, anorexia, } \\
\text { stiff shoulders. }\end{array}$ & $(-)$ & 57 & 283 & 1.00 & \\
\hline 3. & 55 & $\begin{array}{l}\text { Lassitude, fat1gua- } \\
\text { bility, stiff shoul- } \\
\text { ders, Iumbago. }\end{array}$ & $\begin{array}{l}\text { Increased puls pres } \\
\text { sure. }\end{array}$ & 68 & 439 & 0.77 & Iron prep. + \\
\hline 4. & 31 & $\begin{array}{l}\text { Stiffness on shoul- } \\
\text { ders.palpltation, } \\
\text { dysprea. }\end{array}$ & $\begin{array}{l}\text { Accentuated } 2 \text {. pul- } \\
\text { monic sound. }\end{array}$ & 70 & 444 & 0.78 & \\
\hline 5. & 36 & $\begin{array}{l}\text { Weakness of the leg } \\
\text { sleeplessness }\end{array}$ & $\begin{array}{l}\text { Accentuated 2. pul- } \\
\text { monic sound. }\end{array}$ & 62 & 310 & 1.00 & \\
\hline 6. & 38 & $\begin{array}{l}\text { Lagsttude. } \\
\text { hezdache. }\end{array}$ & $\begin{array}{l}\text { Tenderness in the } \\
\text { calf muscle }\end{array}$ & 68 & 329 & 1.03 & \\
\hline 7. & 31 & $\begin{array}{l}\text { Lassitude, palp1ta- } \\
\text { tion, nauses, short- } \\
\text { ress of the breath. }\end{array}$ & $\begin{array}{l}\text { Tendemess in the } \\
\text { calf muscle. }\end{array}$ & 65 & 327 & 0.99 & Iron prep. + \\
\hline$\varepsilon$. & 29 & $\begin{array}{l}\text { Lasst tude, numbness, } \\
\text { neist ation, short- } \\
\text { neas of the breath. }\end{array}$ & $\begin{array}{l}\text { Tenderness in the } \\
\text { calf muscle, hypes- } \\
\text { thesta. }\end{array}$ & 51 & 389 & 0.78 & Iron prep. + \\
\hline 9. & 26 & $\begin{array}{l}\text { Fat1guability, dor- } \\
\text { sal pa:n,lassitude, } \\
\text { ganrexia. }\end{array}$ & $\begin{array}{l}\text { Accent, 2. pulmonic } \\
\text { sound, increased } \\
\text { knee reflex. }\end{array}$ & 61 & 303 & 1.00 & \\
\hline 10. & 44 & $\begin{array}{l}\text { Pa:p1tation, 2ass1- } \\
\text { tude. }\end{array}$ & $\begin{array}{l}\text { Increased knce re- } \\
\text { flex, tenderness in } \\
\text { calf muecle. }\end{array}$ & 50 & 324 & 0.78 & Iron prep. + \\
\hline
\end{tabular}


Tab. 7. The symptoms of the patients with hyperthyroidism who were impressed primarily as beriberi-like state.

\begin{tabular}{|c|c|c|c|c|}
\hline Caseno. & Age $A S E x \mid$ & $\begin{array}{l}\text { Subjective } \\
\text { sympiptome }\end{array}$ & 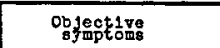 & 期 \\
\hline$\because$ & 23 & $\begin{array}{l}\text { Lagsitude. Fat1gua- } \\
\text { b111ty, paip1tation } \\
\text { tachycard18. }\end{array}$ & $\begin{array}{l}\text { Increased pula pres } \\
\text { sure. }\end{array}$ & +52 \\
\hline 2. & 34 & $\begin{array}{l}\text { Lasest tude, palp1ta- } \\
\text { ilon, tachycardis. }\end{array}$ & 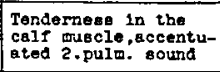 & +73 \\
\hline 3. & 39 & $\begin{array}{l}\text { insegtude, weakreas } \\
\text { of the legs. }\end{array}$ & $(-)$ & +34 \\
\hline 4. & 20 & $\begin{array}{l}\text { iage1 tude, rat1gua- } \\
\text { E111ty, anorex } \mathrm{B} \text {. }\end{array}$ & $\begin{array}{l}\text { Tendornese in the } \\
\text { calf muacio. 1ncrea- } \\
\text { Bed knee reflez. }\end{array}$ & +52 \\
\hline
\end{tabular}

血液像の好転と共に脚父样症状の軽快を認め得た ものがあつた。

甲状腺機能元進怔も表 7 の如く，その症状は脚 気様状態と殆ど区别出来ず，BMRによつて初め て鑑別された。なお弪例 1 はメルカゾールにより BMR+ 5 に改善し，症状も輅快した例で，症例

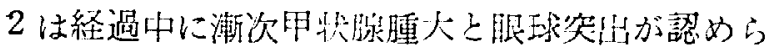

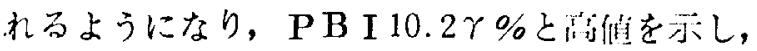

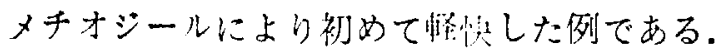

c) 脚父i

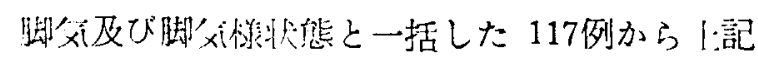
他将患孝除外し，残りの88例中53例に就いて血中

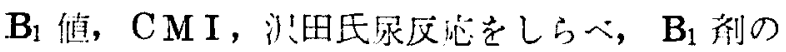
効果との関係をしらへた（攴8）.

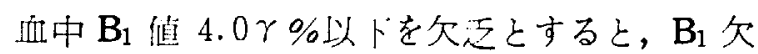

Tab. 8. The relationship among blood thiamine level, CMI, Sawada's urine test and the effect of thiamine.

\begin{tabular}{|c|c|c|c|}
\hline & $\begin{array}{c}\text { Yo. or } \\
\text { petionts }\end{array}$ & 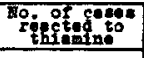 & $\begin{array}{l}\text { 6 of the of- } \\
\text { tocted cosese }\end{array}$ \\
\hline 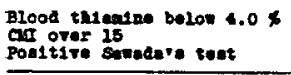 & $\begin{array}{l}23 \\
24 \\
10\end{array}$ & $\begin{array}{r}12 \\
10 \\
9\end{array}$ & $\begin{array}{l}57.1 \\
41.6 \\
50.0\end{array}$ \\
\hline 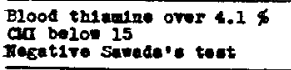 & $\begin{array}{l}52 \\
29 \\
35 \\
\end{array}$ & $\begin{array}{l}2 \\
4 \\
5\end{array}$ & $\begin{array}{l}6.3 \\
13.8 \\
14.3\end{array}$ \\
\hline 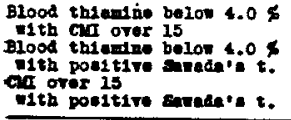 & $\begin{array}{r}10 \\
0 \\
10\end{array}$ & $\begin{array}{l}8 \\
6 \\
5\end{array}$ & $\begin{array}{l}60.0 \\
88.0 \\
60.0\end{array}$ \\
\hline 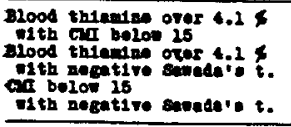 & $\begin{array}{l}18 \\
21\end{array}$ & $\begin{array}{l}0 \\
1 \\
0\end{array}$ & $\begin{array}{l}0.0 \\
4.3 \\
0.0\end{array}$ \\
\hline 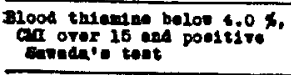 & 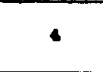 & 4 & 100.0 \\
\hline 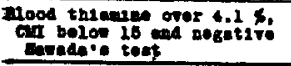 & 26 & 0 & 0.0 \\
\hline
\end{tabular}

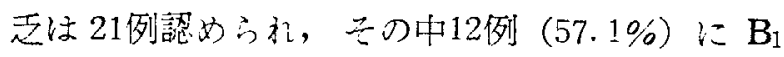
剂が有效であつた。CMIは Horwitt \& Kleisler

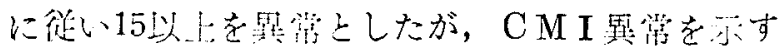
ものは24例で，三の中10例 $(41.7 \%) に \mathrm{~B}_{1}$ 刘が

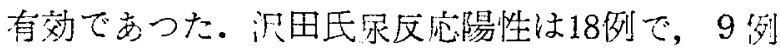
(50.0\%)にB 剂が有效であつた。

血中 $B_{1}$ 傗 $4.1 \gamma \%$ 以, CMI 15以下, 泍田

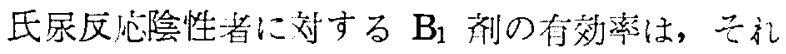
ぞれ $6.3 \%, 13.8 \%, 14.3 \%$ あつた。

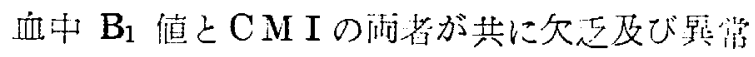
を示す者では， $\mathrm{B}_{1}$ の俏效率は $80.0 \%$ であり，酒

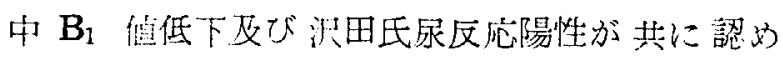
ら礼る者の， $\mathrm{B}_{1}$ 有效率は $88.9 \%$ であつた。 $\mathrm{CM}$

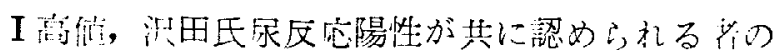
$\mathrm{B}_{1}$ 有效率汶50.0\%にに過ぎなかつた。逆に血中 $\mathrm{B}_{1}$

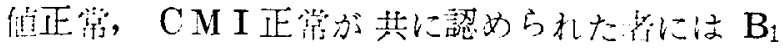

Tab. 9. A differenciation of patients by the level of blood thiamine, CMI and Sawada's urine test and their response to thiamine administration.

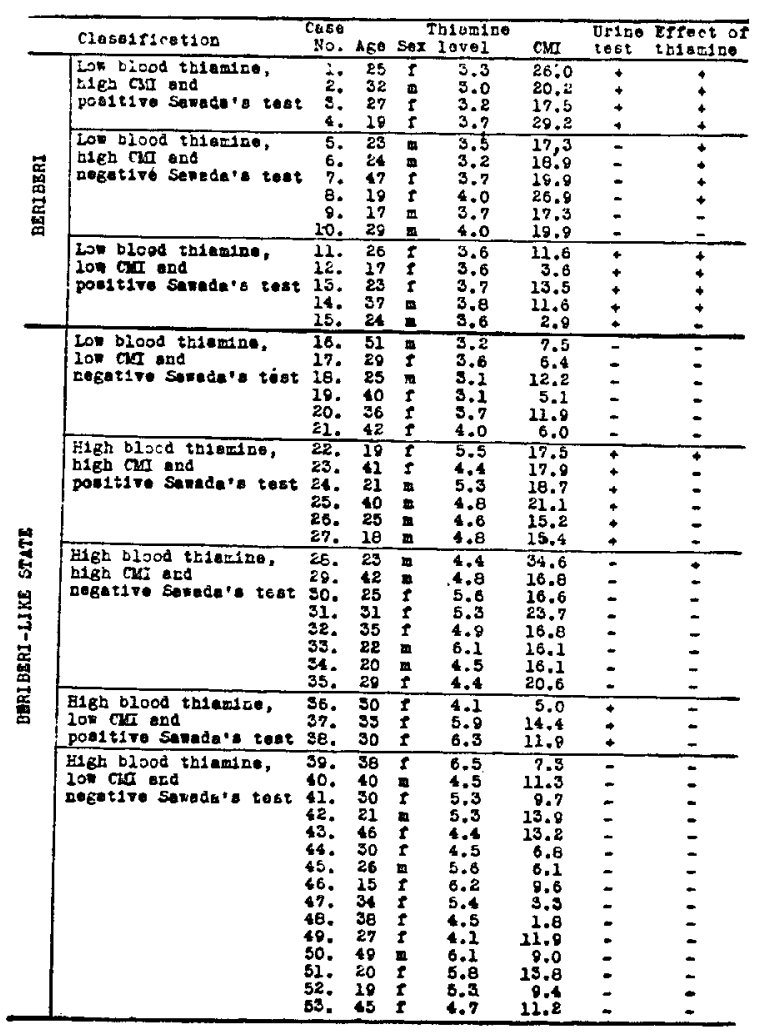




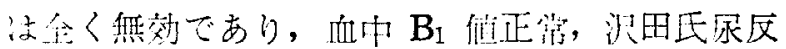

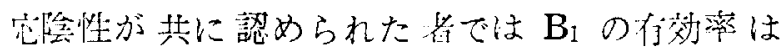
タ.3\%に過ぎなかつた。

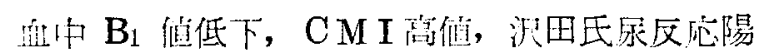
性の三者が共に譛められたものには，企例 $\mathrm{B}_{1}$ 剂 が有效であつた。

そこで血中 $\mathrm{B}_{1}$ 优 $4.0 \% \%$ 以下，CM I 15以上,

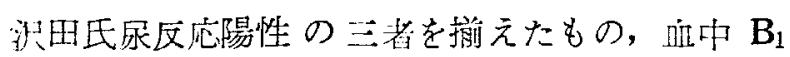
推 $4.0 \% \%$ 以下，沢田氏尿反応陽性の二者学揃え たもの及び， $B_{1}$ 值 4.0 \% \%以下，CMI15以上 の二者を搠えたものを脚気とすると，脚父は53例 中15例 $(28.3 \%)$ となつた。これに対する $\mathrm{B}_{1}$ 剂 の有效率は $80.0 \%$ (15例中12例) であつた（丧 9 ).

d）自律神経失調淀

呼吸沮線の形の不整, 停止（1３0秒以下，停止 (2)が停止（1）より短いものを異常とし，それぞ れ一つを有するものを呼吸異筈（十），二つを存 するものを（\#）、三つを有するものを（卅）とし た。呼吸買常を亦す12例にアトレナリン試験，ピ ロカルピン陚駼を行なうと表10の如く，企例で何 れか一方又は河者に陽性を認め, 又これらに刘す る自倠神経安定剂の有效率は $91.7 \%$ (12例中 11 例）であつた。

脚父及び脚父溙状態53例の㭔吸凅線の異常は， 袁11の如く脚父では15例中（十）は2 例，（サ） 1 例，（卅） 1 例で合計15例中 4 例 (26.7\%) で あつた。脚父以外の38例では（十）11例,

(H)

Tab. 10. The pharmacological test of autonomic function in patients with respiratory abnormality and the effect of vegetative regulator drugs on their clinical findings.

\begin{tabular}{|c|c|c|c|c|}
\hline CaseNo. & $\begin{array}{l}\text { Resplratory } \\
\text { abnormality }\end{array}$ & $\begin{array}{c}\begin{array}{c}\text { dorenalin } \\
\text { teat }\end{array} \\
\end{array}$ & $\begin{array}{c}\text { P1locarpin } \\
\text { teot }\end{array}$ & $\begin{array}{l}\text { Frfect } \\
\text { vegetat pro } \\
\text { regulator }\end{array}$ \\
\hline $\begin{array}{l}1 . \\
2 . \\
3 . \\
4 . \\
5 . \\
6 . \\
7 \\
8 . \\
9 . \\
10 . \\
11 . \\
12 .\end{array}$ & $\begin{array}{r}++ \\
+ \\
+ \\
+ \\
+ \\
+ \\
+ \\
+ \\
+ \\
+\end{array}$ & $\begin{array}{c}++ \\
- \\
+ \\
+++ \\
+++ \\
- \\
- \\
++ \\
+ \\
++ \\
++\end{array}$ & $\begin{array}{c}++ \\
++ \\
+++ \\
- \\
++ \\
+++ \\
++ \\
+ \\
++ \\
+++ \\
++\end{array}$ & 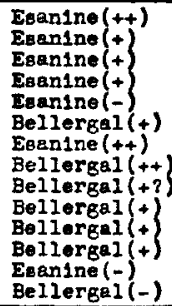 \\
\hline
\end{tabular}

18例，（卅） 3 例，（一４例, 不明 2 例で, 買

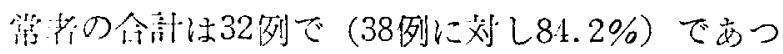
た。これらの界湍省の中17例中14例 $(82.4 \%)$ に は自律神経安足削が有效であり，他の異常渚に対

しては安定剂の効果を追跡できなかつた。

Tの減高は表12の如く，健康者 8 例の平均值は $\mathrm{TI}=0.03 \pm 0.02 \mathrm{mV}, \mathrm{T}_{\mathrm{II}}=0.04 \pm 0.05 \mathrm{mV}, \mathrm{V}_{\mathrm{III}}=$ $0.07 \pm 0.04 \mathrm{mV}$ であり，自律神経安定剂有效例11 例の平均健は $\mathrm{TI}=0.05 \pm 0.05, \mathrm{~T}_{\mathrm{II}}=0.11 \pm 0.05$, TIII $=0.07 \pm 0.05$ で, TII のみ健康者に比较し て， $0.01<\mathrm{P}<0.02 て ゙$ 存意の隔优を示した. TII

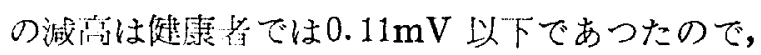

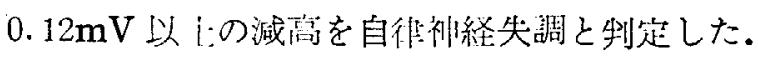

Tab. 11. The findings of respiratory test and the change in $T$-hight at the standing position in patients with beriberi and beriberi-like state, compared with the effect of vegetative regulator drugs. (B.H. (1) means breath-holding time after resting respiration. B.H. (2) means breath-holding timeafter hyperventilations, reg. means regular, irr. means irregular.)

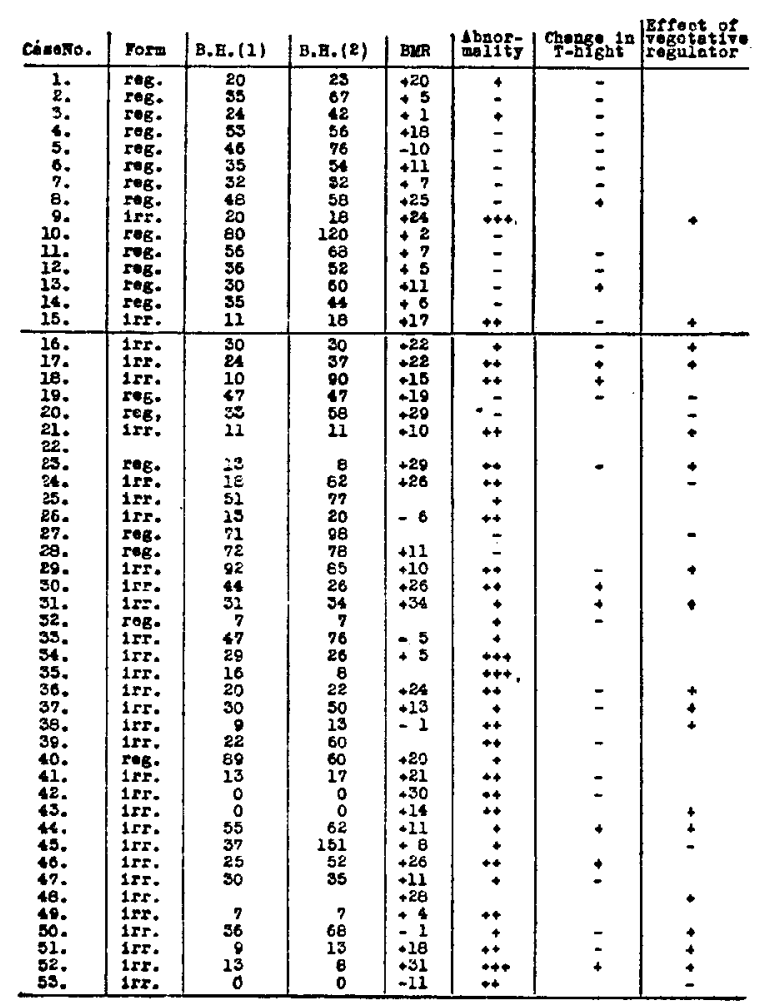


Tab. 12. The change in T-hight at the standing position in normal persons and patients with autonomic imbalance.

\begin{tabular}{|c|c|c|c|c|c|c|c|}
\hline \multicolumn{4}{|c|}{ Normal peraons } & \multicolumn{4}{|c|}{ Pationts with outcn. 1mb. } \\
\hline Ceseno. & $\mathbf{n}$ & T. & Tw & Casezon. & $T_{t}$ & ns & $\mathbf{T}_{\mathbf{m}}$ \\
\hline $\begin{array}{l}1 . \\
2 . \\
3 . \\
4 . \\
5 . \\
6 . \\
7 . \\
8 .\end{array}$ & $\begin{array}{l}0.04 \\
0.00 \\
0.04 \\
0.00 \\
0.01 \\
0.05 \\
0.07 \\
0.00\end{array}$ & $\begin{array}{l}0.08 \\
0.05 \\
0.05 \\
0.07 \\
0.00 \\
0.07 \\
0.11 \\
0.03\end{array}$ & $\begin{array}{l}0.04 \\
0.08 \\
0.05 \\
0.05 \\
0.02 \\
0.08 \\
0.09 \\
0.14\end{array}$ & $\begin{array}{l}40 . \\
42 . \\
43 . \\
45 . \\
50 . \\
51 . \\
15 . \\
16 . \\
19 . \\
24 . \\
26 .\end{array}$ & $\begin{array}{l}0.00 \\
0.15 \\
0.05 \\
0.08 \\
0.01 \\
0.11 \\
0.05 \\
0.00 \\
0.01 \\
0.05 \\
0.06\end{array}$ & $\begin{array}{l}0.09 \\
0.20 \\
0.03 \\
0.10 \\
0.11 \\
0.15 \\
0.05 \\
0.22 \\
0.11 \\
0.08 \\
0.11 \\
\end{array}$ & $\begin{array}{l}0.09 \\
0.03 \\
0.05 \\
0.02 \\
0.15 \\
0.04 \\
0.09 \\
0.08 \\
0.15 \\
0.03 \\
0.02\end{array}$ \\
\hline \multicolumn{4}{|c|}{$T \geqslant 0.02 \pm 0.05$} & \multicolumn{4}{|c|}{$x_{1} 0.05 \neq 0.05$} \\
\hline \multicolumn{4}{|c|}{$T=0.06 \div 0.06$} & \multicolumn{4}{|c|}{$T: 0.11 \pm 0.05^{n}$} \\
\hline \multicolumn{4}{|c|}{$0.05 \pm 0.03$} & \multicolumn{4}{|c|}{$T=0.07 \pm 0.05$} \\
\hline
\end{tabular}

その結梁は表11の如く，脚父で異掌の減窝を示し

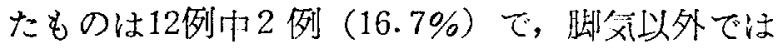
19例中 6 例 $(31.6 \%)$ であつた。

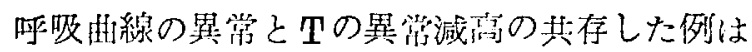
脚父にはなく，趾父以外には 7 例を認め，その中 自律种経安定剂の效果を確め得た 4 例は全て存効 であつた。しかし白推神経罗定䘞有效で，呵吸州 總の買学を認めながら，Tの異散減高のないもの \&7例に認められた。

e ）脚父及び脚父梯状態の臨床宊状のみによ る分類との対比

以上の成結で脚父は15例，自律神経失调炡沙少 なくとも14例である。これらを臨床昰状のみから 脚父と脚父样状態に分けると表13の如くなる，症 状による分類は，脚気様主訴 $S$ ，神経筋症状 N (腱反射の買労労, 知敩買常, 腓腸筋握痛及び硬結), 心血管症状 C（脈の異常, 第 II 肺動脤音直進, 最 低血理降下), 浮腫 $\mathrm{O}$ の中, $\mathrm{S} \mathrm{NCO}$ 久は $\mathrm{S} \mathrm{N} \mathrm{C} \mathrm{を}$ 揃えたものを脚父とし，その他を脚父様状態とし

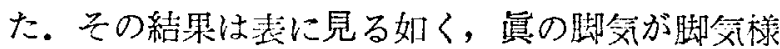
状熊の中にも大り，又自律神経先調症も臨床症状 に上り分整した㱓氛の中に含まれた。

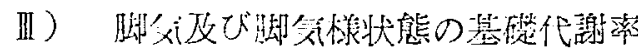

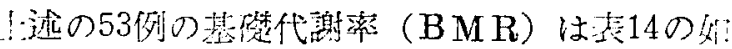

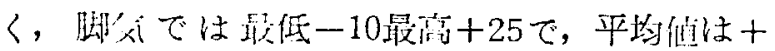
$9.0 \pm 8.5$ である。自律被経失調将では最低一 1 ，

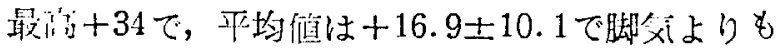

や〉高倘を示した。この中には+30より高いもの が 3 例(表11)亦つたが，その中で最筒を示した十

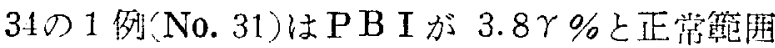
内にあり，他の 2 例洅度の検査で十 2 及び+15 を示した。なお例とも呼吸曲線は不整を示した。

III） Wenger 氏の自律神経緊张状態測定法の 成縝

これら53例の兒律补経異常を，Wenger 氏の自 律神経緊張状態測定法により検討した。

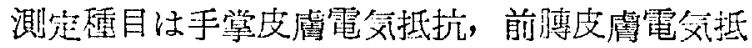
抗，心拍間隔，舌下温度，最高血压，最低血沓， 整液分泌聂を採り，测定法は国文9）の方法に従つ た。健康人対照としては東邦大学病院の医師，看 護婦, 不び某刑務所受刑者合計 100 人(男女同数)

Tab. 13. A differentiation of the patients with beriberi and beriberi-like state by their clinical symptoms.

S: subjective symptom

$\mathrm{N}$ : neuro-muscular symptoms (increased, diminished or absent knee of Achilles tendon reflex, hypesthesia, tenderness in the culf muscle)

C: cardio-vascular symptoms (rapid, soft, large and celer pulse, lowered minimal blood pressure, accentuated second pulmonic sound, enlarged right heart)

$\mathrm{O}$ : edema

\begin{tabular}{|c|c|c|c|}
\hline & & $\begin{array}{c}\text { Pationte with } \\
\text { beriberi }\end{array}$ & 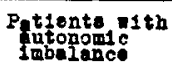 \\
\hline Beriber1 & $\begin{array}{l}\text { Skco } \\
\text { sre }\end{array}$ & 5 & 1 \\
\hline $\begin{array}{l}\text { Beriber1- } \\
\text { I1ke } \\
\text { Etate }\end{array}$ & $\begin{array}{l}\text { SEO } \\
\text { SCO } \\
\text { SN } \\
\text { SC } \\
\text { so } \\
\text { s }\end{array}$ & $\begin{array}{l}4 \\
5 \\
1\end{array}$ & $\begin{array}{l}7 \\
1 \\
1 \\
4\end{array}$ \\
\hline
\end{tabular}

Tab. 14.The basal metabolic rate in patients with beriberi and autonomic imbalance.

\begin{tabular}{l|c|c}
\hline & Beriberi & $\begin{array}{c}\text { Autonomic } \\
\text { imbalonce }\end{array}$ \\
\hline Mean & $+9.0 \pm 8.5$ & $+16.9 \pm 10.1$ \\
\hline Range & $-10 \sim+25$ & $-1 \sim+34$ \\
\hline
\end{tabular}


Tab. 15. The correlation matrix in Wenger's test of autonomic balance.

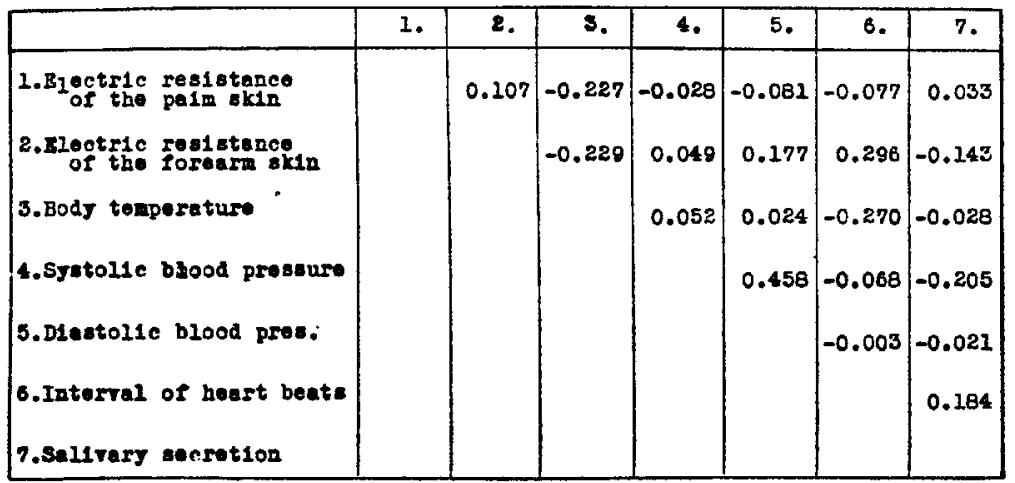

Fig. 3. The histogram in Wenger's factor analysis.

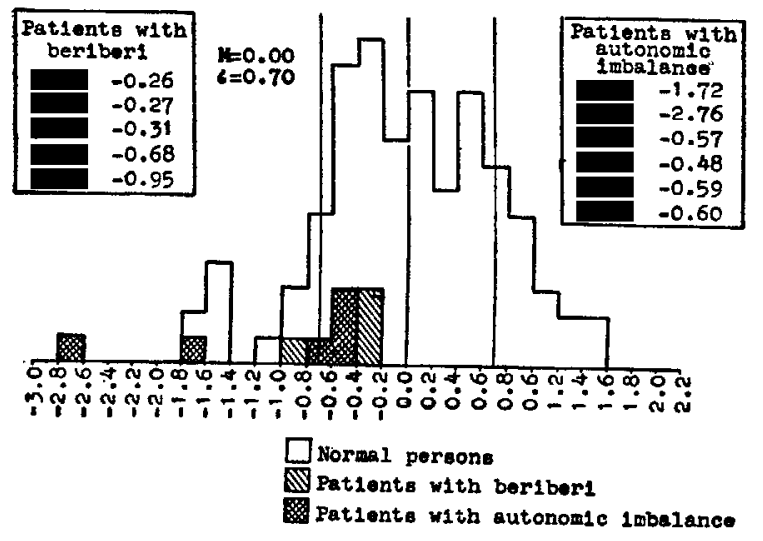

を選んだ，患者との条件を出来るだけ等しくす るために，測定期間は昭和33年 9 月 1 日から30日 迄とし，測定時間は午前 9 時より12時迄とした。 年令は患者の年令分布を考慮して15才から48才迄 とした．室温は $21^{\circ} \mathrm{Cから} 34^{\circ} \mathrm{C} に$ 亘つた。従つて測 定法の吟味を行なつた結果，年令に対しては手学 皮膚電気抵抗，心拍間隔，気温に対しては前膊皮 膚電気抵抗，舌下温度，最低血圧，心拍間隔，唾 液分泌量がそれぞれ補正を要した。相関行列は表 $15 に$ 示す通りで，符号も想定変化とほ心゙一致し た. 因子分析の結果第 1 因子に自律神経平衡因子 を得ることが出来た。これより各個人の因子得点 を計算すると，平均值0.00土0.700正規分布を示 し，その分布は図2 の如くなつた。この場合(一) は交感神経優越方向を, (十) は副交感神経優越 方向を示している。
Tab. 16. The effect of various kinds of drugs on the patients with beriberi and beriberilike state.

\begin{tabular}{|c|c|}
\hline & -rfocted pationt \\
\hline Thlemine derivatives & 14 \\
\hline Vegetative roguletors & 11 \\
\hline 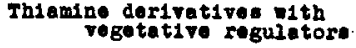 & 5 \\
\hline Tranquil1zor & 2 \\
\hline Tentosterone & 2 \\
\hline Sponteneouely healed & 7 \\
\hline Unknomn & 12 \\
\hline
\end{tabular}

上述の53例中，この検查を追求したものは，9 月1日から30日間に来院したものに限つた。その 得点を脚気と自律神経失調者に分けて見ると図 2 の如く，画群とも交感神経優越を示し，副交感神 経優越を示したものは 1 例もなかつた。健康人の 平均值の標準偏差 $\sigma= \pm 0.70$ より交感神経優越方 向に傾いたものは，脚気群で 1 例，自律神経失調 者群では2 例で，他は総べて標準㣂差の範囲内で あつた。

\section{IV) 治療成績}

上記53例の治療成續と 3 カ月後の遠隔成續は表 16の如くである.

$\mathrm{B}_{1}$ 剂の有効例は 14例である。その中 2 例は脚 気と診断されたものではない，自律神経安定剂の みの有効なものは 11例であつた。 $\mathrm{B}_{1}$ 剂のみでは 無効で, 自律神経安定剤を併用して初めて効果を 諗めたものが脚氛に2 例（No. 9，No. 15）脚気 以外に 3 例 (No. 16, No. 17, No. 21) あり, こ の3 例は， $\mathrm{B}_{1}$ 值の低いものであつた，又これら 
5 例は絰へて呼吸曲線の異常を示している。其の 他休養したら治つたものや，澺しくなつたら治つ たもの等自然治癔が 7 例あり，䅣乃の才法を陚み ても治痛しないものが 5 例あつた。なお性ホルモ ン(罗性ホルモン)が著効を京した例が 2 例あり， 精神安定喃の奏效したものも2 例あつた。

\section{考案}

脚氛及び脚気椂状態の吥究をす〉める場会，第 一にこのような患者を如何にして把握するかぶ問 題となる．特に脚氛様状態は，一定の定蓄に基つ いた一定の範疇がないだけにこれを把握するに は，脚気様主訴を基にして，その中から他将㭧を 消去して行く以外に方法がない。

然るに脚冬様主訴が，脚気历至脚父様状態に特 有なものでないことは云うまでもなく，殆ど総べ ての聅患の主訴となり得る。脚父椂主訴を有する 患者を疾患別に分類して見ると，その大部分は高 血纴症, 肺結核, 胃炎, 䀒炎, 神経症等の聅患に分 類され，これらの疾患を脚父及び脚父様状態以外 の他栬患として見ると，その占める割合は，表 1 の如く脚父様主訴者の57.8〜 85.6\%にも達する.

これらの他疾患に属さないものは，㑢父及び脚 気様状態と洘えざるを得ない。しかしてこの中か ら賁の脚父を区別することは極めて困難であつ て, 従つて私はこれらを一括して，「脚父及び脚 気様状態」とした。

これらの患者の発生頻度は, 決して少なくな く，年々ほほ一定してはいるが，表 1 の如く外来 初診患者総数に対して，その $2.8 〜 7.1 \%$ の多き に達している．しかもこの中に顕性脚気とすべき ものは 1 例もなく，何れも極めて軽症のものばか りである.

さきにも述へたた如くこれらは只慢然と $\mathrm{B}_{1}$ 欠 症であると考えられがちであるが，この中から 脚気の他に脚気様状態とも云うべき病態が緟に区 別され杖ばらないことは，既に大森4によって 指摘された処であり，佐々3）も $\mathrm{B}_{1}$ の有効な軽症 脚父门至は不全型脚氛と $\mathrm{B}_{1}$ の船効な脚氛様状態 ガこの中に混在していることを述べている。
このような脚父模状態の成立機転に関しては， 既に種々の推察がなされており，大森4)は脚気様 状態は独立した病態でない場合が多く結核，栄養 失調症, 腎性浮腫, 心性浮腫, 袙経㴤, 疲学状 態, 消化器疾患, 病桨感染聇, 多発性神経炎, 春 骫仿㳊患，不全型パルキンソニスムス等の，脚気と 多少とも発生病理学上，因果循環的関係にある原 病によつて招来されるために，これらと鑑別する 必装のあることを説いている。车大鈴5)はいわゆ る不全型或は未熟型脚父の自他覚的症状が全く神 経循環性袞弱と同じである所から，その一部は脚 父様症状群であつて，更にその中には帊経循環性

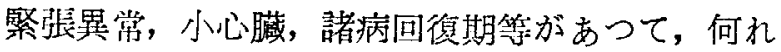
も自律神経不安定にあると主張している，更に北 沃 ${ }^{(6)}$ は脚気様愁訴に脚父に特徽的な心血管症状, 神経筇症状の三つを揃えたもの，及びこれに浮腫 を加えたものを脚笑とし，心血管症状，神経筋症： 状の中何れかを欠く場合は, 神経循環不全站であ り, 脚父様愁訴のみで他覚的所見のないものは神 経循環衰弱症であるとし，脚父様状態がこのよう な神経循環性繁張異常に基づいていることを認め ている.古閵は又，これらを不定症候群なる名称 で一括しこえと迷彩結核との鑑別について詳述: している。

以上の諸説を要約すると脚父梯状態の中には， 1)鑑別すべき他疾患，2)異の脚気，3)自律神経異. 常の三つが混在しているとの推論がなされている と解釈される。

鑑別すべき他疾患の混在は，云うまでもなく診 断の精度の問題であつて, 私が刘象としたものは 外来の日常診療において普通に行なわれる診断技 術によって分汁出された脚気及び脚氛様状態であ. つて,診断の精度を高めた私の研究で, 表 6 及び 7 の如き貧血症や甲状腺機能圥進症等が表 5 の如く 鑑別し出されたことは，むしろ当然のことではあ， るが，上記の推論を端的に実踣している，最近小 宮10)等は，鉄欠乏性貧血発症の前症とも云うべき 血清鉄欠乏症(Sideropenia)について言及し、こ れが，全身传总感，易疲性等の症状を有し，しか も血液所見には異常なく，血清鉄の測定によって 
のみ診断し得るものであることを述べている。こ のことは，上記の如き軽症貧血患者の混在と併せ 孝えて興味樑いことである。私がな预不明とせ和 ばならなかつたものっ中には,このような Sideropenia を含めて, 更に他疾患が湿在している可能 性もあるであろうが，この点は今後の検討にまち たい。

さて以上の如き他疾患を除いたものは, 脚気及 び脚気梯状態とされる。この中から脚気を如何に 分類し出すかに関しては, 種乃の試みがなされて いるが，一定した方法が確立されていない，血中 $\mathbf{B}_{1}$ 值は最もしばしば脚気診断の指標とされる。 脚気が生体内 $\mathrm{B}_{1}$ 欠乏を主因とすることは疑う余 地がないがこの発症に関しては, 内外の種々の 因子が関係するといわれている4)。従つて特に軽 症の場合には血中 $\mathbf{B}_{1}$ 值の低下は，それのみで繁 密な脚気診断の指標とはならない。しかし私は前 述の成續から一応 $4.0 \gamma \%$ 以下を $\mathrm{B}_{1}$ 欠乏として 取扱かつた。

沢田氏尿反店も脚気において高率に陽性を示す ために，従来しばしば脚氛の診断に用いられてい る.しかしこれは脚気以外に肝疾患, 副交感神経 緊张状態, 疲労等においても陽性を示す. 徒つて 测田はこれらの鑑别を目的とした方法を発表し た.この方法によつても私の成績では，血中 $\mathrm{B}_{1}$ 值の場合と同様に單独では脚気診断の的中率が低 かった。

脚気のもう一つの指標として, 血中乳酸値や焦 性ブドウ酸值の上界が挙げられている.教室の成 績11》よればこれらの脚気及び脚気様状態にお いては, 空腹安静時の血中乳酸值及び焦性ブドウ 酸值は, 総へて正常範囲内にあつて一定の関係を 見出すことが出来なかつた。これはこのような極 めて軽症な脚気では, 空腹安静時の糖質代謝は異 常を来たさないためと考えられる。しかして糖及 び運動の負荷を行なうならば，糖質代謝に何らか の異常が起こり得ることが想像される．従つてこ の運動及び糖負荷による脚気検索手段である所の C M I はより督れた方法であると考えられる.
血中 $\mathrm{B}_{1}$ 值と $\mathrm{CM} I$ との閒に推計学上貧の相関 のあることを認めたが，これによつてもCMIの 有価性は推察される。しかし乍ら Horwitt 等も 警告しているょうに，CMIの示す糖筫代謝異常 は，必ずしも $\mathrm{B}_{1}$ 欠乏のみによつて起こるもので なく，他の成因による糖質代謝異常によつても高 值を来たすことがある．私の成續でも（表 9 ) $\mathrm{B}^{\mathrm{I}}$ 欠走がない場合で CMIが高值を示し，しかも $\mathrm{B}_{1}$ 郕の無効な症例が多数誋められた。

以上の如く血中 $\mathrm{B}_{1}$ 值, 沢田氏尿反応, CM I はそれそれ脚文の密接な関係にあるが，なお絶体 的なものではない。こ〉に三者を併用する理由も あるが，私の成績では血中 $\mathrm{B}_{1}$ 值と沢田氏尿反応， 血中 $B_{1}$ 值と $\mathrm{CM} I$ 质び血中 $\mathrm{B}_{1}$ 值, $\mathrm{CMI}$, 沢 田氏尿反応の三者を併用することの有価性が証明 された。

私はこの万法により脚気を抽出し得たが，残り のものは脚気様状態となる理である。このもの> 成因の中で, 最も老えられやすいのは, 前述の如 く神経循環衰弱症を含めた自律神経失調の存在で あつてこの点は諸家の論ずる所にまつまでもな く，私の統計的観察の中にも示されている．元来 自律神経は外界の気温気湿, 気任の影響を受けや すく,従つて高温, 高湿の夏期に, 自律神経系への 負担が增大し, 失調性素因を有する患者では, 失 調症状の発現が助長される. 又若年者に失調症の 多いことは Clauser も認める所である. 即ち私 の成續で, これらの患者が, 夏期に多く, 若年者 に多い結果は，むしろこのような臣律神経应によ つて影響された点の多いことを裹づけている。

自律神経機能検查法には種々の方法があるが, 何れも種タの問題をはらんでいて確定されていな い. 私は比較的測定が容易で, 実用性のあること に留意し, 先ず呼吸曲線と立位心電図Tの減高を 選んだ。

神経循環衰弱症において呼吸曲線の不整が認め られることは, 既に White \& Hahn ${ }^{12) や ~ C o h e n ~}$ 等13)によつて指摘され, Mark' ${ }^{14)}$ も自律神経失調 者にこのことを認めている. 㕛村15)も心葴神経 
症にこの現象を認め，しかもこれが Bellergal で 改善されることを見ている。亩律神経緊張異 常, 特に心臟神経症の時に呼吸停上時間方短縮す

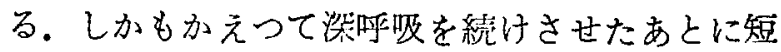

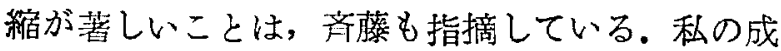
續でも,これらの認められるものは, 総へてアト レナリン試験又はピロカルピン試験陽性を示し,

このような患者に自律神経安定剤が可成高率に奏 効している．從つてこのような呼吸の異常は自律 神経異常の検絮手段として可成り役立つように思 われる。

起立性循環障害の患者で立位Tの減高が認めら れることは， Nordenfelt ${ }^{16)}$ が指摘している. 及 彼は，酒石酸エルゴタミンがこの現象を抑制する と云う。木村15)は神経循罯衰弱症においてその客 観的所見として立位Tの減高が意味を有し，これ が Bellergal で抑制されると云い，從つて自律神 経緊張異常と密接な関係にあることを述へてい る．私の成續では，しかし乍らTの減高は健康人 でも多数に認められ，減高の程度を問題にする必 要があるように考えられた。減高の程度はT⿰七 おいて，健康人と自律神経失調者との間に推計学 的に有意の差が認められた。しかし年ら私の成績 では, 自律神経安定剤が有効で，しかも呼吸曲線 に異常を示すもので，な抒 TrI の減高の著しくな いものもあり，個々の正例を検討する場合に，一 定の傾向を求め難く，正常値の限界を定めること は困難である. 私は一応 $\mathrm{TII}=0.12 \mathrm{mV}$ の減高を 以つて正常限界とすることにした。

脚気と脚気以外の自律神経安定剂有効例とを比 䡈すると，呼吸曲線では脚気に異常を示すものが 少なく，安定剤有效例では異常を示すものが多 い. 従つて, 脚気にも起こり得ることが考えられ る所の自律神経異常は, 呼吸曲線に示される自律 神経異常とは異質のものであり，従つて私の認め た自律神経異常者は，脚気と独立したものと考え られる。一方下減高ではこのような做问は少ない ように思われる。

私は以上の方法により脚気様状態を分析し，そ
の少なくとも $26.4 \%$ 自律神経失調症であること を実恠した。これらは何れも脚気と独立して自律 神経機能に異常を認め, 自律神経安定剂の有效疗 点から確められたものばかりであるが，この他に 自律神経機能に異常を認め乍ら, 自律神経安走削 の效果を試し得なかつた症例（15例）もあつて， その中には高㻭に自律袖経失調が含まれているこ とが予想される。従つて実際には自律神経失調怔 の占める割合は，はるかに大となることが推祭さ れる。

以上私は脚気溙状態として一括したもの〉中 に, 真の脚気の他に自律神経失調症の存在するこ とを実証したが，この点より検討して従来の脚公 々脚気様状態を臨床症状のみより区別せんとする 試みが無力であることを知つた。

自律神経失調症のBMRが一般にや〉高值を示 すことは Mark ${ }^{14)}$ む認めている，私の成續でもこ れと一致した。

Wenger の自律神経㙨能検查の成績で, 脚父群 も自律神経失調者群も共に交感神経優越を示し た。自街神経失調者群の 2 例は特に著しく卒感神 経優越方向に傾いているが，脚艾の 1 例も同様で あり，両群の間に著明な差はない。すへて交感神 経優越に傾いた点は，或は国父 ${ }^{9)}$ の云う如き情緒 反応が強く影響しているためとも考えられるが， 例数が少なく，なお今後の検討にまちたい。

治療成續では，私の方法で診断した脚気で15例 中12例に $\mathrm{B}_{1}$ 剂が有効であり， $\mathrm{B}_{1}$ 剂の無効であつ た 3 例中 2 例む自律神経安定剂の併用により $\mathrm{B}_{1}$ 剤が効果を示した. 又 $\mathrm{B}_{1}$ 欠乏と無関係の自律神 経失調者群では, $\mathrm{B}_{1}$ 剂は無効で, 殆どの例は自律 神経安定剤が有效であつた。即ち，私の行なつた 診断方法によれば，それに即した治療法を行なう ことが出来, しかも治療効果も高められる。私の 成績では表16の如く脚気及び脚気様状態として一 括した53例の中30例はこのような分析結果から治 撚せしめ得たものであり，その治爒効果は $56.6 \%$ の治瘜率となつている。

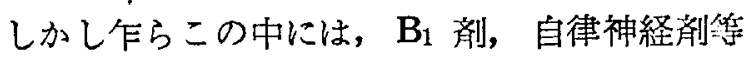


何れの方法をもつてしても全く治癗せしめ得なか つた症例もあり，又性ホルモンの著效を示した例 もあつて，なおその本態を掴み得なかつた症例も 少なくない。これらに就いては, 内分泌系を含め た別の病態生理学的解明を要すると思われるが， この点は今後の研究にまちたい。

\section{結 論}

1）臨床上脚気及び脚気様状態と一括される患 者は, 外来総患者数の $2.8 \sim 7.1 \%$ に達し, 年 アほメ゙一定の割合を示している。この中には顕性 即気は全く見られず，又その増加の傾问もない。

2）これらの患者は，他の軽症疾患とまぎらわ しく, 詳細に検查すると, その $24.8 \%$ はな扡疾 患として除外されねばならない。

3）軽症脚気を診断する場合，血中 $\mathrm{B}_{1}$ 值と $\mathrm{C}$ $M I$, 血中 $B_{1}$ 值と沢田氏尿反応の二者併用が可 成り有効であり，血中 $\mathrm{B}_{1}$ 值，沢田氏尿反応， $\mathrm{C}$ M I 三者が異常を示す場合は脚気の診断は確実性 が高い.

4）脚気様状態の中には自律神経失調に基づく むのが少なくない。

5）脚気及び脚気様状態と一括した患者を，血 中 $\mathrm{B}_{1}$ 值及び糦代謝, 自律神経機能の面より分析 検討した結果, 臨床症状のみの分類によつて真の 脚気をこれらの中から分離することの困難なこと を知つた。
6）基礎代謝率では，脚気に比し自律神経失調 を有するもの>方がや>高めであつた，Wenger の自律神経緊張状態測定法では, 脚気も自律神経 失調を有するものでも,すへて交感神経優越を示 し，雨者に差異を認め得なかつた。

7）脚気及び脚気様状態を以上の観点から分析 しそれに即した治療を行なうことによりその治 瘾率を高めることが出来た。

(本論文の要旨は第 $54,55,56$ 回日本内科学会総会に おいて発表した)。

\section{考交献}

1)篠崎有三: 日内会誌, $44: 1093$ (昭31). - 2)柳 金太郎：日医会誌, $32: 73$ (昭29). 脚気 (昭30) 金 原出版株式会社. 一 - 3) 佐々貫之: 日医会誌, 32: $73($ 昭29). - - 4) 大森憲太 : 臨床暦程 (昭24), 日本 医事新報社，一5）大敛弘文：衫断々治痖，39： 500 (昭26)。心矌神経庭 (昭27) 医学書院。一-6) 北沢：医学垀論，2:1 (昭25), 一7) 沢田：ビ タミン, $14: 291$ (1958). - 8) Horwitt \& Klejsler: J. Nutrit. $37: 411(1949)$. - - 9) 国又好 : 慈 医大誌, $73: 1632$ (昭33). - 10) 小宮：日本医事新 報, No. 1811, P 33(昭34)。一11) 阿部他 : 日内会誌, 46 : 474 (昭32), - 12) White \& Hahn: Am. J. Med. Sci., 177 : 179 (1929). - 13) Cohen: Med. Clin. North. Am., 33 : 1343 (1949). - 14) Mark: Klinik u. Therapie d. veget. Dystonie Springer-Verlag. Wien. (1954)。 - 15) 木村采 一他: 治療, 39 ：462（昭32). - 16) Nordenfeld: Zeitschr. Kleislaufforschg., 31 : 761 (1939). 